\title{
Identification of $\beta$-endorphins in the pituitary gland and blood plasma of the common carp (Cyprinus carpio)
}

\author{
E H van den Burg, J R Metz, R J Arends, B Devreese', \\ I Vandenberghe ${ }^{1}$, J Van Beeumen ${ }^{1}$, S E Wendelaar Bonga \\ and G Flik
}

\author{
Department of Animal Physiology, Faculty of Science, University of Nijmegen, Toernooiveld 1, 6525 ED Nijmegen, The Netherlands \\ ${ }^{1}$ Laboratory of Protein Biochemistry and Protein Engineering, University of Gent, KL Ledeganckstraat 35, B9000 Gent, Belgium \\ (Requests for offprints should be addressed to G Flik; Email: gertflik@sci.kun.nl)
}

\begin{abstract}
Carp $\beta$-endorphin is posttranslationally modified by $\mathrm{N}$-terminal acetylation and C-terminal cleavage. These processes determine the biological activity of the $\beta$-endorphins. Forms of $\beta$-endorphin were identified in the pars intermedia and the pars distalis of the pituitary gland of the common carp (Cyprinus carpio), as well as the forms released in vitro and into the blood. After separation and quantitation by high performance liquid chromatography (HPLC) coupled with radioimmunoassay, the $\beta$-endorphin immunoreactive products were identified by electrospray ionisation mass spectrometry and peptide sequencing. The release of $\beta$-endorphins by the pituitary gland was studied after stimulation with corticotrophinreleasing factor (CRF) in vitro. In the pars intermedia, eight $\mathrm{N}$-acetylated truncated forms were identified. Full length $\mathrm{N}$-acetyl $\beta$-endorphin(1-33) coeluted with
\end{abstract}

$\mathrm{N}$-acetyl $\beta$-endorphin(1-29) and these forms together amounted to over $50 \%$ of total immunoreactivity. These products were partially processed to N-acetyl $\beta$ endorphin(1-15) (30.8\% of total immunoreactivity) and $\mathrm{N}$-acetyl $\beta$-endorphin(1-10) (3.1\%) via two different cleavage pathways. The acetylated carp homologues of mammalian $\alpha_{-}$and $\gamma$-endorphin were also found. $\mathrm{N}$-acetyl $\beta$-endorphin(1-15) and (1-29) and/or (1-33) were the major products to be released in vitro, and were the only acetylated $\beta$-endorphins found in blood plasma, although never together. CRF stimulated the release of opioid $\beta$-endorphin from the pars distalis. This nonacetylated $\beta$-endorphin represents the full length peptide and is the most abundant form in plasma.

Journal of Endocrinology (2001) 169, 271-280

\section{Introduction}

Beta-endorphin is a pro-opiomelanocortin (POMC)derived peptide and is predominantly produced in the pituitary gland and the brain. Its bioactivity depends on C-terminal truncation and N-terminal acetylation. For instance, $\beta$-endorphin(1-31) is a very potent opiate, whereas its acetylated congener is essentially devoid of opioid activity (Akil et al. 1981). On the other hand, C-terminal cleavage produces the very effective opioid antagonist $\beta$-endorphin(1-27) (Nicolas \& Li 1985).

In addition to its opioid function, $\beta$-endorphin was found to be involved in a variety of physiological processes (reviewed by Dalayeun et al. 1993), including regulation of the immune (Heijnen et al. 1987, Shahabi et al. 1991, 1996) and reproductive (e.g. Faletti et al. 1999) systems. Furthermore, $\beta$-endorphin plays a role in the vertebrate stress response (e.g. Akil et al. 1985, Kjær et al. 1995, Wendelaar Bonga 1997, Mosconi et al. 1998).
Since forms of $\beta$-endorphin exert different biological effects, research so far has focused on the occurrence of $\beta$-endorphins that may each have different actions. Posttranslationally modified $\beta$-endorphins have been described in a variety of vertebrates, including teleost fish (Takahashi et al. 1984) and mammals (Weber et al. 1981, Smyth 1984, Millington et al. 1992). However, data on the release and functions of $\beta$-endorphins are very scarce. In human blood plasma, the major form is $\beta$-endorphin(1-31) (Silberring et al. 1998). In fish, $\mathrm{N}$-acetyl $\beta$-endorphin immunoreactivity has been reported in plasma (Rodrigues \& Sumpter 1984, Sumpter et al. 1985, Mosconi et al. 1998), although the exact nature of the forms responsible for this immunoreactivity is unknown.

Recent cloning of carp POMC (Arends et al. 1998) showed that full length $\beta$-endorphin in this species consists of 33 amino acid residues, rather than 31 amino acids as in mammals and other vertebrates, and contains one potential dibasic and five potential monobasic cleavage sites. Therefore, identification of $\beta$-endorphins in the pituitary gland 
predicts how processing of carp $\beta$-endorphin takes place and how this relates to processing in mammals. In addition to this evolutionary perspective, it is also of great interest to study processing of $\beta$-endorphin isoforms from a physiological point of view, as $\mathrm{N}$-acetyl $\beta$-endorphin may have corticotrophic activity in teleosts (Balm et al. 1995).

Thus, the present study aimed to identify posttranslationally modified $\beta$-endorphin isoforms in the pars intermedia and the pars distalis of the pituitary gland of the common carp (Cyprinus carpio). Furthermore, we analysed which truncated forms are released in vitro and which are present in the blood plasma. Finally, the effects of corticotrophin-releasing factor (CRF) on $\beta$-endorphin release by the pituitary gland were assessed by means of in vitro superfusion. CRF stimulates the release of adrenocorticotrophic hormones such as adrenocorticotrophic hormone (ACTH) and $\alpha$-melanocyte-stimulating hormone $(\alpha-\mathrm{MSH})$ during stress (Wendelaar Bonga 1997). The analysis of CRF-driven $\beta$-endorphin release may indicate whether any $\beta$-endorphins are secreted during stress.

\section{Materials and Methods}

\section{Animals}

Male carp (70-120 g) were obtained from laboratory stock. Fish were held in 100 litre tanks within a recirculating system supplied with UV-filtered and biologically filtered tap water. The water temperature was maintained at $22{ }^{\circ} \mathrm{C}$ and the daily photoperiod was $16 \mathrm{~h}$. Fish were fed commercial fish food (Trouvit, Trouw, Putten, The Netherlands) at $1 \cdot 5 \%$ of body weight per day.

\section{Tissue preparation}

Fish were anaesthetised in 0.1\% 2-phenoxyethanol. One millilitre blood was collected from the caudal blood vessels using a 21-gauge syringe with $\mathrm{Na}_{2}$ EDTA as antiagglutinant. One trypsin inhibitor unit (TIU) aprotinin (Sigma, St Louis, MO, USA) per ml plasma was added to prevent proteolytic breakdown. After centrifugation $\left(500 \mathrm{~g}, 10 \mathrm{~min}, 4{ }^{\circ} \mathrm{C}\right)$, plasma was collected and used immediately. To obtain the pituitary gland, the fish were placed on ice directly after the blood had been collected. The pituitary gland was then removed and the pars intermedia and pars distalis were separated with the aid of a dissection microscope. The tissue was homogenised mechanically on ice in $100 \mu \mathrm{l} 10 \mathrm{mM} \mathrm{HCl}$ and $0 \cdot 2 \mathrm{TIU}$ aprotinin. After centrifugation $\left(10000 \mathrm{~g}, 10 \mathrm{~min}, 4^{\circ} \mathrm{C}\right)$ to remove membranes and cellular debris, the supernatant was submitted to reversed-phase HPLC immediately or after storage at $-20{ }^{\circ} \mathrm{C}$.

\section{Prepurification of plasma}

A Pharmacia LKB Superdex-75 HR 10/30 column (Pharmacia LKB Biotechnology, Uppsala, Sweden) was used for initial purification of plasma. The eluent consisted of an $0.36 \mathrm{M}$ acetate buffer $(0.088 \mathrm{M}$ ammonium acetate, $0 \cdot 272 \mathrm{M}$ acetic acid, $19 \% \mathrm{v} / \mathrm{v}$ ethanol, $\mathrm{pH} 4 \cdot 4$ ), as described by Sælsen et al. (1994). The flow was $0.5 \mathrm{ml} / \mathrm{min}$, and $300 \mu \mathrm{l}$ fractions were collected. One hundred microlitres of the fractions were vacuum-dried and redissolved in veronal acetate buffer: VAT-buffer, $\mathrm{pH} 8 \cdot 6,0.02 \mathrm{M}$ sodium barbital, $0.2 \mathrm{~g} / 1 \mathrm{NaN}_{3}$, supplemented with $0 \cdot 3 \%$ bovine serum albumin (Sigma), and $100 \mathrm{KIU} / \mathrm{ml}$ trypsin inhibitor (Trasylol; Bayer, Leverkusen, Germany), and analysed by radioimmunoassay.

\section{Radioimmunoassay}

$\mathrm{N}$-acetyl $\beta$-endorphin was quantitated in duplicate by radioimmunoassay with an antiserum against salmon $\mathrm{N}$-acetyl $\beta$-endorphin (developed and characterised by Takahashi et al. 1984). This antibody has full crossreactivity with acetylated forms of mammalian (Dores et al. 1991) and Xenopus (Van Strien et al. 1993) $\beta$-endorphin. Cross-reactivity of this antibody with non-acetylated forms is less than $0 \cdot 1 \%$ (Dores et al. 1991). The final dilution of the antiserum was 1:250 000. Xenopus $\mathrm{N}$-acetyl $\beta$-endorphin(1-8) used as tracer was iodinated using the iodogen method (Salacinsky et al. 1981) and purified through solid phase extraction (octadecyl Bakerbond column). Immunocomplexes were separated from free tracer by precipitation of the complexes with $15 \%$ polyethylene glycol and $2 \cdot 4 \%$ ovalbumin.

\section{Reversed-phase HPLC}

Immunoreactive Superdex-75 fractions obtained from blood plasma samples were vacuum dried and resuspended in $100 \mu 10 \mathrm{mM} \mathrm{HCl}$. These samples, as well as the pars intermedia and pars distalis homogenates, were submitted to reversed-phase HPLC using a $\mu \mathrm{RPC} \mathrm{C} 2 / \mathrm{C} 18$ SC2 1/10 column (Amersham Pharmacia Biotech AB, Uppsala, Sweden). Beta-endorphins were separated with an acetonitril gradient (22-36\%) in water containing $0 \cdot 1 \%$ trifluoroacetic acid (Merck, Darmstadt, Germany) at $150 \mu \mathrm{l} / \mathrm{min}$. Fractions $(300 \mu \mathrm{l})$ were dried under vacuum and redissolved in VAT-buffer for radioimmunoassay. Standards were human $\alpha$-endorphin, human $\gamma$-endorphin, $\mathrm{N}$-acetyl $\beta$-endorphin(1-27) (Sigma) and Xenopus $\mathrm{N}$-acetyl $\beta$-endorphin(1-8) (American Peptide Company, Santa Clara, CA, USA).

\section{Affinity chromatography}

To assess the presence of non-acetylated $\beta$-endorphin, homogenates of pars intermedia and pars distalis, as well as Superdex-75-fractions of plasma, were submitted to affinity chromatography to deplete the samples of $\mathrm{N}$-acetyl $\beta$-endorphins. An affinity column was prepared according 
to the manufacturer's instructions (Pharmacia) using the anti-N-acetyl $\beta$-endorphin antibody. The samples were eluted with $2 \mathrm{ml} 0 \cdot 1 \mathrm{M} \mathrm{Na}_{2} \mathrm{CO}_{3}, \mathrm{pH} 8 \cdot 0$, and subsequently vacuum-dried. The pellets were redissolved in $10 \mathrm{mM} \mathrm{HCl}$ and submitted to reversed-phase HPLC. To measure non-acetylated $\beta$-endorphins, samples were chemically acetylated as described by Van Strien et al. (1993). Briefly, $100 \mu \mathrm{l}$ of sample was dried under vacuum and resuspended in $100 \mu \mathrm{l} 50 \mathrm{mM}$ phosphate buffer, $\mathrm{pH} 8 \cdot 0$. Acetylation was started by adding $2 \mu \mathrm{l}$ acetic anhydride (Sigma), followed by vigorous vortexing. Samples were dried and resuspended in VAT-buffer for radioimmunoassay for acetylated endorphins.

\section{In vitro superfusion}

The pars distalis and pars intermedia were separated and were placed on a cheese-cloth filter in a superfusion chamber and superfused with a Hepes-buffered $(15 \mathrm{mM}$; $\mathrm{pH} 7 \cdot 38)$ Ringer's solution containing $\mathrm{NaCl}(128 \mathrm{mM})$, $\mathrm{KCl}(2 \mathrm{mM}), \mathrm{CaCl}_{2} \cdot 2 \mathrm{H}_{2} \mathrm{O}(2 \mathrm{mM})$, with $0 \cdot 25 \%$ (w/v) glucose and $0.03 \%(\mathrm{w} / \mathrm{v})$ bovine serum albumin. Medium was pumped through the chambers at $30 \mu \mathrm{l} / \mathrm{min}$ by a Watson-Marlow 503U multichannel peristaltic pump (Smith and Nephew Watson-Marlow, Falmouth, Cornwall, UK). After $180 \mathrm{~min}$ superfusion, when the release of endorphins had reached an apparent steady state, ovine CRF (Sigma) was added to the medium to a final concentration of $1 \mathrm{nM}$ to test its effect on the release of $\beta$-endorphin isoforms. A 20 -min fraction before and a 20 -min fraction during the pulse were collected in $50 \mathrm{mM}$ $\mathrm{HCl}$ and analysed for the presence of $\beta$-endorphin isoforms as described above.

\section{Molecular weight determination by electrospray ionisation mass spectrometry (ESMS)}

Partially purified $\beta$-endorphin immunoreactive peptides were analysed on a Micromass Q-TOF mass spectrometer (Wythenshawe, Manchester, UK), fitted with a nanoelectrospray ion source. Lyophilised peptides were dissolved in $50 \%$ acetonitril $/ 1 \%$ formic acid in water; the final peptide concentration was approximately $1 \mu \mathrm{M}$ (based on the theoretical molecular weight of the peptide). Four microlitre aliquots of sample solutions were loaded into borosilicate Nanoflow tips (Protana, Odense, Denmark). The mass spectrometer (MS) was operated in positive ion mode with a source temperature of $30{ }^{\circ} \mathrm{C}$. A potential of $0 \cdot 8-1 \cdot 5 \mathrm{kV}$ applied to the Nanoflow tip combined with a nitrogen backpressure of 5-10 psi produced a sample flow of $10-30 \mathrm{nl} / \mathrm{min}$ into the analyser. All data, both MS and MS/MS, were acquired with the TOF analyser. In MS/MS mode the quadrupole was used in resolving mode to select the precursor ion for fragmentation in the hexapole collision cell. MS/MS was performed with argon gas in the collision cell at a pressure of $6 \times 10^{-5} \mathrm{mbar}$ measured in the analyser. All data were processed using Masslynx software delivered with the instrument.

\section{Peptide sequencing}

Peptides were sequenced by automated Edman degradation in a model 476 pulsed-liquid sequenator (Applied Biosystems, Foster City, CA, USA).

\section{Peptide synthesis}

Carp N-acetyl $\beta$-endorphin(1-10) was synthesised by the Institute of Infectious Diseases and Immunology, Faculty of Veterinary Medicine, Utrecht University, The Netherlands. Carp $\beta$-endorphin(1-29) was synthesised by the Department of Immunohaematology and Bloodbank, Leiden, The Netherlands.

\section{Immunohistochemistry}

Brain-pituitary gland complexes were fixed in Bouin's fixative. Sagittal sections $(7 \mu \mathrm{m})$ were immunostained with the peroxidase-anti-peroxidase method, according to Van der Heijden et al. (1999) with minor modifications, using the salmon $\mathrm{N}$-acetyl $\beta$-endorphin antibody as described above or a carp $\beta$-endorphin(20-29) antiserum (1:2000). The latter antibody was produced in our laboratory by immunising rabbits with carp $\beta$-endorphin(20-29) coupled to keyhole limpet haemocyanin. The antiserum recognises acetylated as well as non-acetylated full length carp $\beta$-endorphin and carp $\beta$-endorphin(1-29). Serum specificity was assessed histochemically by omitting the antiserum and by replacing the antiserum with normal rabbit serum. Immunostaining was fully abolished in these tests. The sections were subsequently incubated with this antibody (overnight), goatanti-rabbit IgG (1:150; 1 h; Nordic Immunology, Tilburg, The Netherlands), rabbit peroxidase-anti-peroxidase (1:150; $1 \mathrm{~h} ;$ Nordic) and 3,3-diaminobenzidine tetrahydrochloride $(0 \cdot 25 \mathrm{mg} / \mathrm{ml})$ in the presence of $0 \cdot 0005 \%$ (v/v) $\mathrm{H}_{2} \mathrm{O}_{2}$ for $5 \mathrm{~min}$.

\section{Statistics}

Six fish were sampled to quantitate and identify the forms of $\beta$-endorphin in blood plasma, pars intermedia and pars distalis. Basal and CRF-stimulated release of $\beta$-endorphins was studied in quadruplicate, whereas the immunohistochemical analysis of distribution of $\beta$-endorphins in the brain-pituitary gland complexes was performed on three fish. As little variation between replicates occurred, results are presented as representative examples, unless stated otherwise.

\section{Results}

Seven immunoreactive fractions were observed in homogenates of the pars intermedia (Fig. 1) containing 


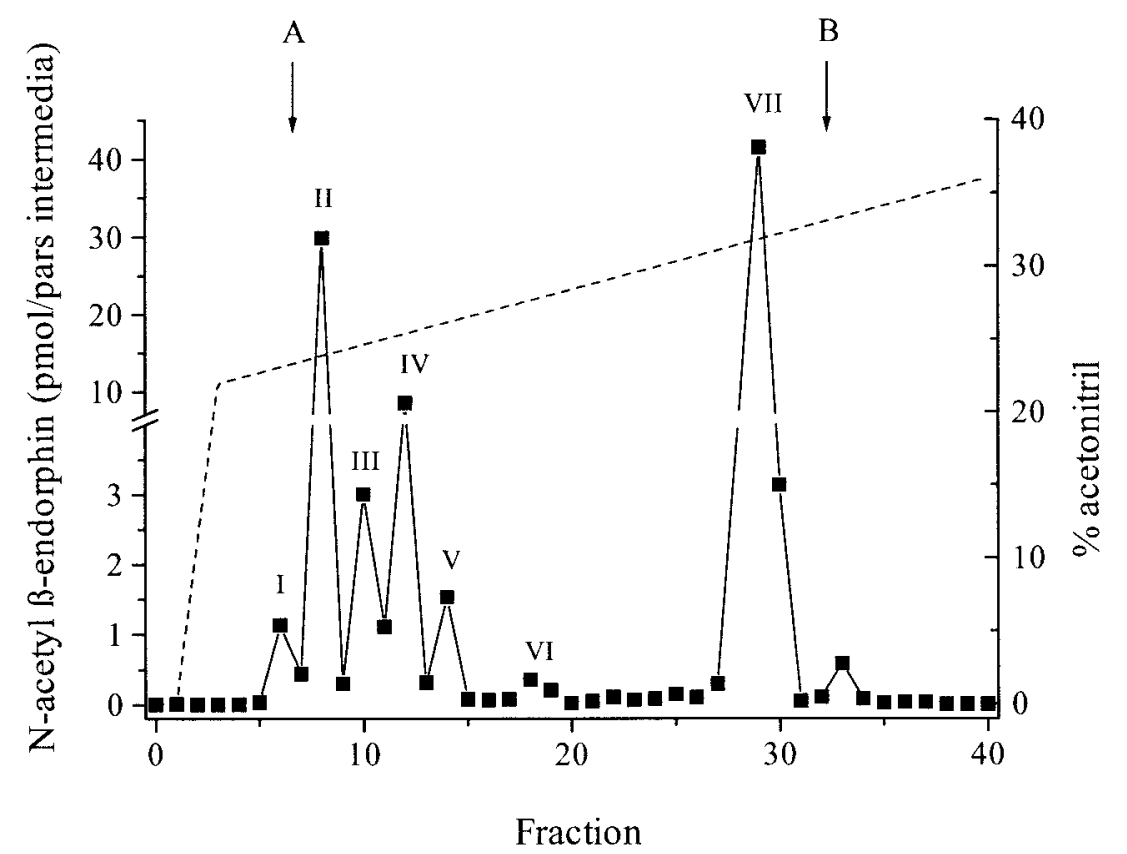

Figure 1 Reversed phase analysis of carp $\mathrm{N}$-acetyl $\beta$-endorphin in the pars intermedia. The dashed line represents the acetonitril gradient in water, ranging from $22 \%$ in fraction 3 to $36 \%$ in fraction 40 . Seven immunoreactive fractions were obtained containing $\mathrm{N}$-acetyl $\beta$-endorphin(1-10) (I), N-acetyl $\beta$-endorphin(1-15) (II), N-acetyl $\beta$-endorphin(1-16) (III), $\mathrm{N}$-acetyl $\beta$-endorphin(1-18) (IV), $\mathrm{N}$-acetyl $\beta$-endorphin(1-17) (V), $\mathrm{N}$-acetyl $\beta$-endorphin(1-19) (VI) and $\mathrm{N}$-acetyl $\beta$-endorphin(1-29) and (1-33) (VII). The following standards were chromatographed separately: A, Xenopus $\mathrm{N}$-acetyl $\beta$-endorphin $(1-8)$; $\mathrm{B}$, human $\mathrm{N}$-acetyl $\beta$-endorphin(1-27).

8 N-acetyl $\beta$-endorphins. Peak VII contained 50.5\% of the immunoreactivity and represented $\mathrm{N}$-acetyl $\beta$-endorphin(1-29) plus (1-33), as determined by ESMS and peptide sequencing. The other predominant $\beta$-endorphin eluted in peak II $(30 \cdot 8 \%)$, and was found to be $\mathrm{N}$-acetyl $\beta$-endorphin(1-15). N-acetyl $\beta$ endorphin(1-16) (peak III, 3.8\%), N-acetyl $\beta$-endorphin(1-17) (peak V, 1.8\%), N-acetyl $\beta$ endorphin(1-18) (peak IV, 9.4\%), and $\mathrm{N}$-acetyl $\beta$-endorphin(1-19) (peak VI, $0 \cdot 6 \%$ ) were the other constituents. The identity of the $\mathrm{N}$-acetyl $\beta$-endorphin in peak I $(3 \cdot 1 \%)$ could not be assessed by ESMS. However, we observed the presence of $\beta$-endorphin(12-29) in fraction 14 , indicating that $\mathrm{N}$-acetyl $\beta$-endorphin $(1-29)$ is cleaved at the single basic residue $\operatorname{Arg}^{11}$ to yield $\mathrm{N}$-acetyl $\beta$-endorphin(1-10). Synthetic carp $\mathrm{N}$-acetyl $\beta$-endorphin(1-10) was found to elute in fraction 6, indicating that peak I contains this peptide.

One peak reflecting non-acetylated $\beta$-endorphin was obtained (peak VIII, $1 \cdot 7 \%$, Fig. 2). We were unable to identify this peptide with ESMS. The immunoreactive product was found to coelute with synthetic carp $\beta$-endorphin(1-29) (data not shown), and, in parallel to the acetylated forms, probably also with $\beta$-endorphin(133). Beta-endorphin(1-29) and (1-33) are the most hydrophobic forms (as predicted from their amino acid composition) and thus the apparent immunoreactivity eluting in later fractions cannot represent $\beta$-endorphin. Immunoreactivity in these fractions (e.g. fractions 18 and 19 in Fig. 2), when present, is very low and therefore considered not specific. Fraction 5 always shows some immunoreactivity, but we were unable to identify its nature.

The pars intermedia released four forms in vitro (Fig. 3), of which $\mathrm{N}$-acetyl $\beta$-endorphin(1-29) and/or (1-33), and $\mathrm{N}$-acetyl $\beta$-endorphin(1-15) were predominant. The other secreted products were $\mathrm{N}$-acetyl $\beta$-endorphin(1-10) and (1-18). The two former peptides were also found in plasma, but never simultaneously in the same fish (Fig. 4). Blood plasma from three fish contained $\mathrm{N}$-acetyl $\beta$-endorphin(1-15), whereas plasma from the other three fish contained $\mathrm{N}$-acetyl $\beta$-endorphin(1-29). The $\mathrm{N}$-acetyl $\beta$-endorphin concentration in blood plasma was $3.7 \pm 0.6 \mathrm{nmol} / 1$ (mean \pm s.E.M, $n=6$ ). The concentration of the non-acetylated $\beta$-endorphin in plasma (Fig. 5, peak VIII) varied considerably among individual fish and ranged from 7 to $84 \mathrm{nmol} / 1$.

In vitro stimulation of the pars intermedia with $1 \mathrm{nM}$ CRF did not stimulate release of any $\beta$-endorphin (data not shown). On the other hand, the secretion of 


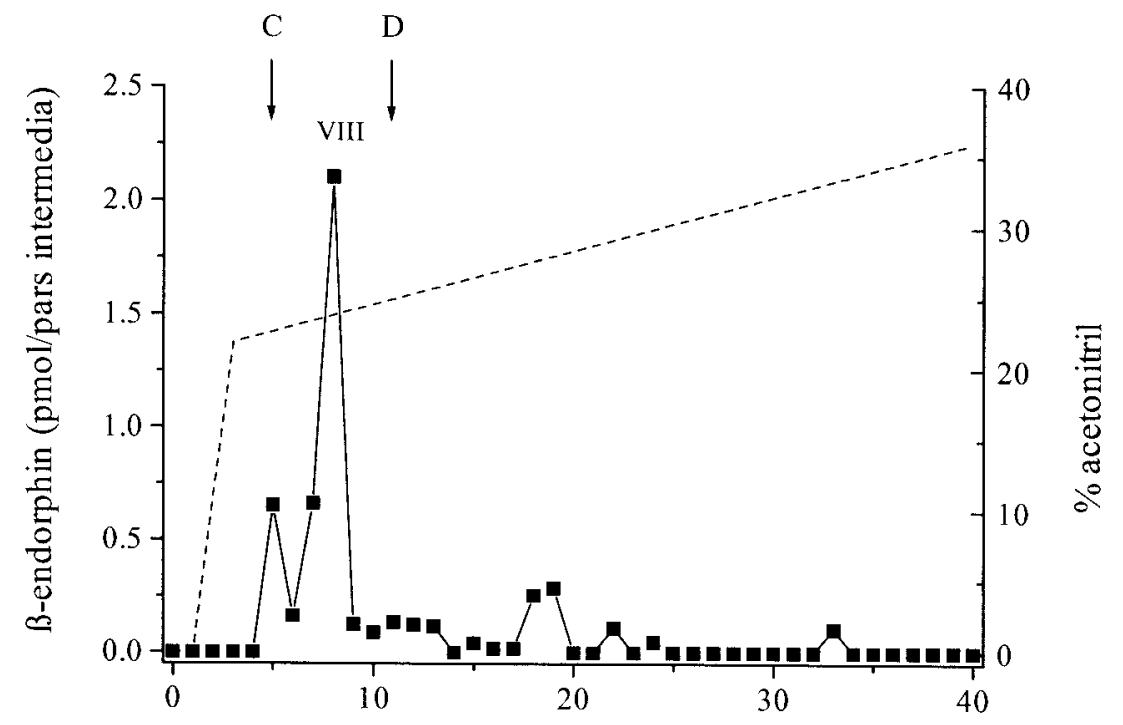

Fraction

Figure 2 Reversed phase analysis of carp $\beta$-endorphin in the pars intermedia. (Dashed line: acetonitril gradient in water; conditions as in Fig. 1.) Aliquots of immunoreactive fractions were further analysed by electrospray mass spectrometry, which did not reveal the identity of $\beta$-endorphins. Synthetic carp $\beta$-endorphin(1-29) coeluted in fraction 8 with peak VIII.

The following human standards were chromatographed separately: $\mathrm{C}$, $\alpha$-endorphin;

D, $\gamma$-endorphin.

non-acetylated $\beta$-endorphin was promoted in the pars distalis: basal release was almost undetectable but when stimulated with CRF the release increased to $57 \mathrm{fmol} / \mathrm{min}$ per pars distalis (Fig. 6).
Non-acetylated $\beta$-endorphin was localised in the nucleus preopticus (NPO) and in the hypothalamopituitary tract (Fig. 7). The $\beta$-endorphin-containing neurons spread throughout the pars intermedia (PI).

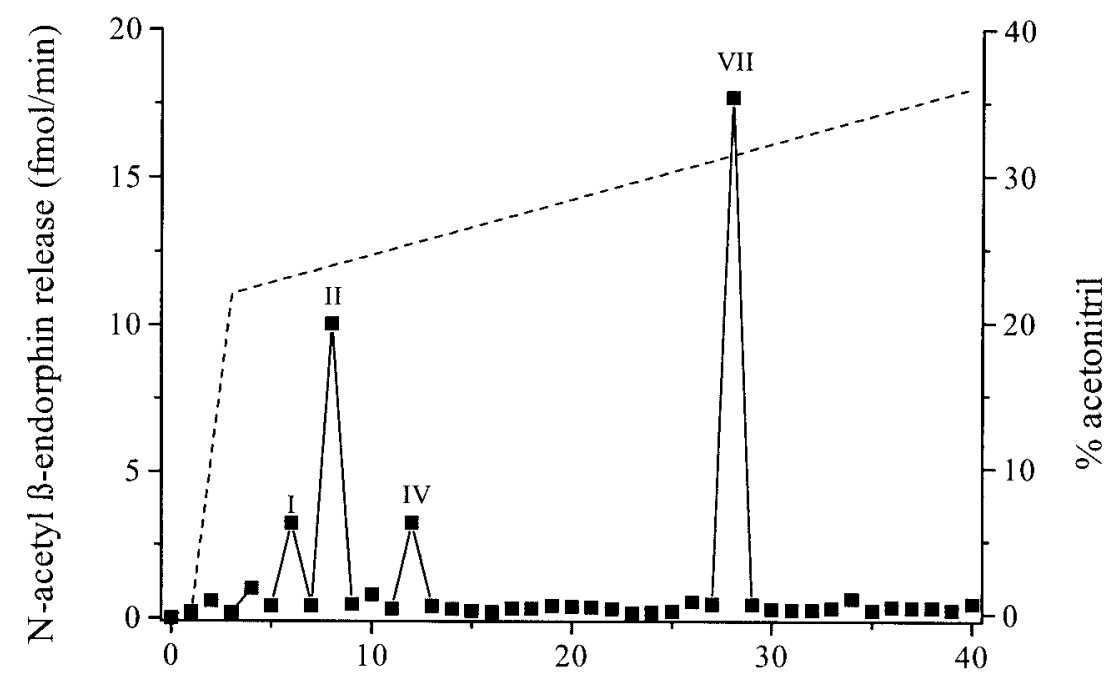

Fraction

Figure 3 Basal in vitro release of carp $\mathrm{N}$-acetyl $\beta$-endorphin(1-10) (peak I), (1-15) (peak II), (1-18) (peak IV), and (1-29)/(1-33) (peak VII). (Conditions as in Fig. 1.) 


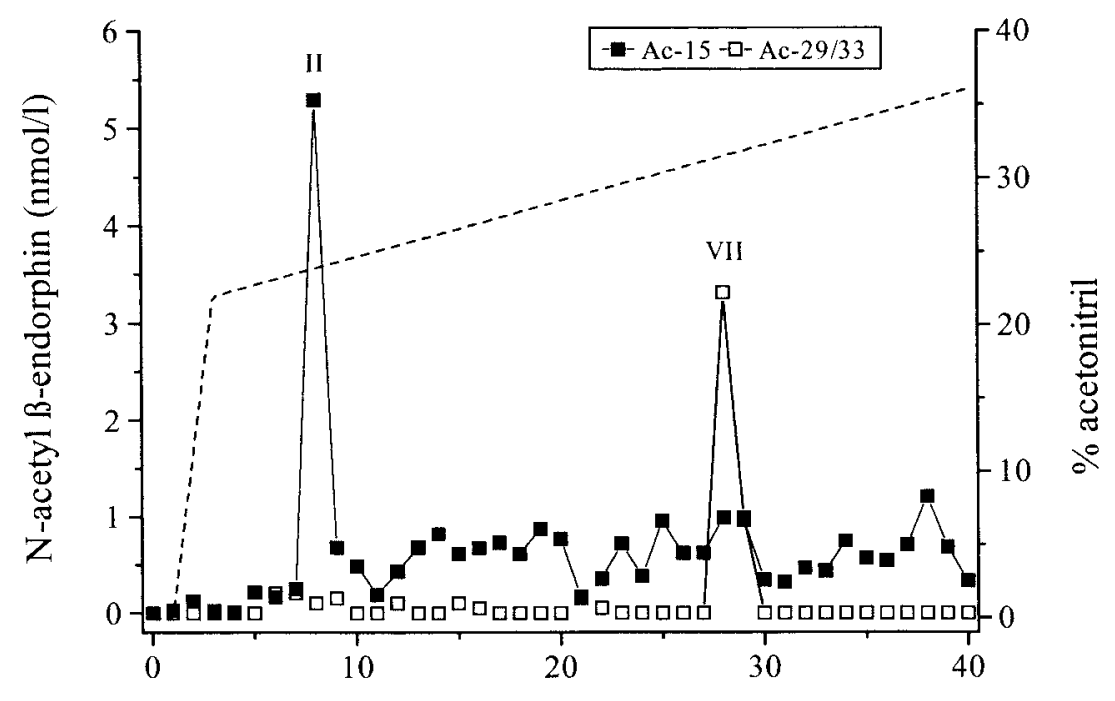

Fraction

Figure 4 Reversed phase analysis of carp $\mathrm{N}$-acetyl $\beta$-endorphin in blood plasma. Samples from six fish were analysed, three of which contained $\mathrm{N}$-acetyl $\beta$-endorphin(1-15) (peak II, Ac-15), whereas plasma from the other fish contained $N$-acetyl $\beta$-endorphin(1-29) or (1-33) (peak VII, Ac-29/33). (Conditions as in Fig. 1.)

Non-acetylated $\beta$-endorphin was not detectable by immunohistochemistry in the pars distalis (PD). The immunostaining of the melanotroph cells in the PI reflects the presence of $\mathrm{N}$-acetyl $\beta$-endorphin(1-33) and (1-29). Immunostaining with the antibody against acetylated $\beta$-endorphins only stained the melanotroph cells in the pars intermedia.

\section{Discussion}

We identified eight acetylated $\beta$-endorphins in the pars intermedia. $\mathrm{N}$-acetyl $\beta$-endorphin(1-33) is the full length peptide (Arends et al. 1998), and its cleavage follows two pathways to yield either $\mathrm{N}$-acetyl $\beta$-endorphin $(1-10)$ or (1-15). The first pathway involves cleavage of $\mathrm{N}$-acetyl

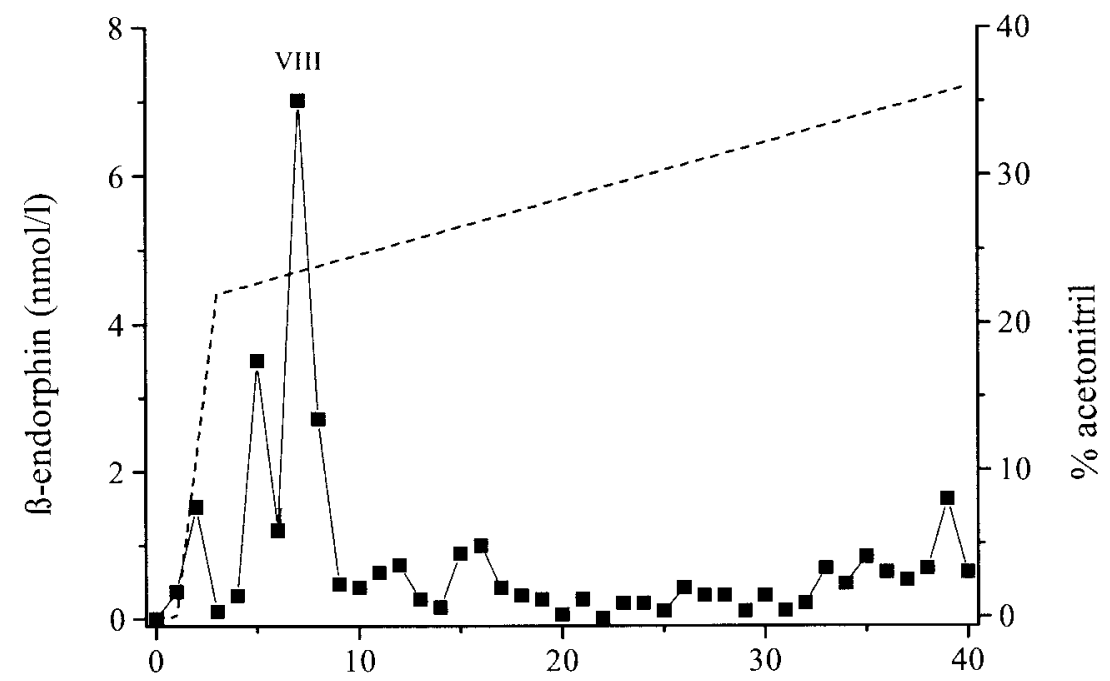

Figure 5 Reversed phase analysis of carp $\beta$-endorphin in plasma. Peak VIII coelutes with carp $\beta$-endorphin(1-29). (Conditions as in Fig. 1.) 


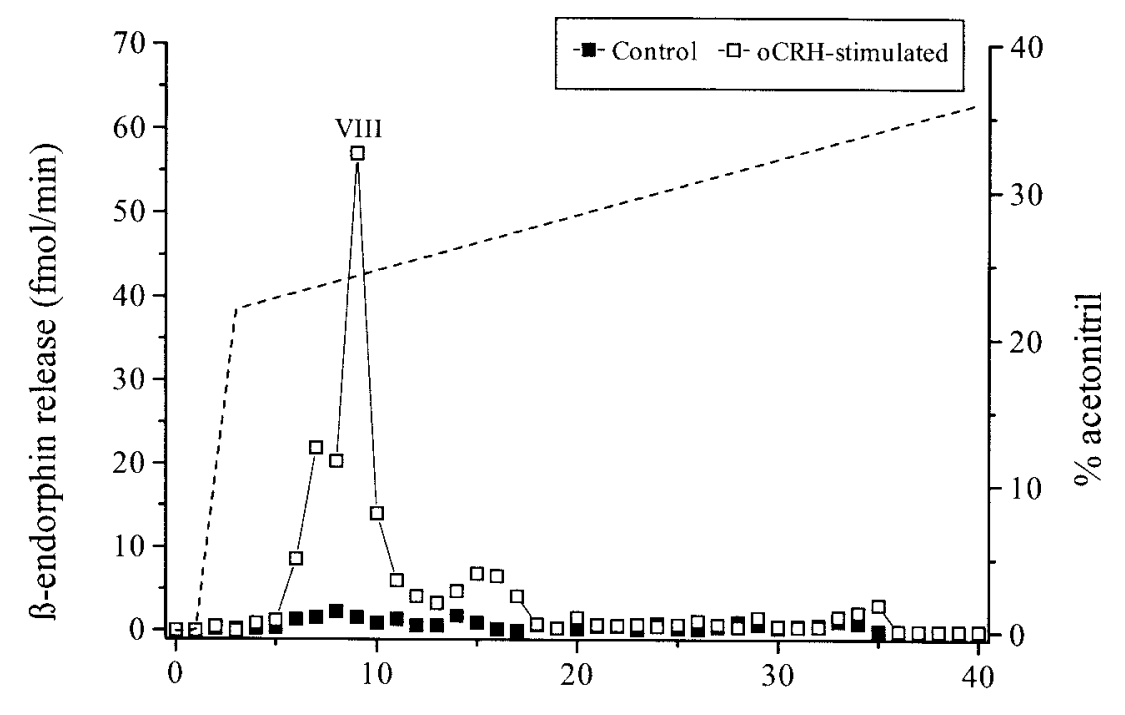

Fraction

Figure 6 Reversed phase analysis of in vitro CRF-driven $\beta$-endorphin release from the pars distalis. The control consists of non-acetylated $\beta$-endorphin release during the $20 \mathrm{~min}$ preceeding the 20-min pulse with CRF on the same tissue. Peak VIII coelutes with carp $\beta$-endorphin(1-29). (Conditions as in Fig. 1.)

$\beta$-endorphin(1-33) to $\mathrm{N}$-acetyl $\beta$-endorphin(1-29) at the dibasic cleavage site Lys $^{30}-$ Lys $^{31}$ by prohormone convertase 2 (PC2; Zhou et al. 1993). Next, this peptide is cleaved at $\operatorname{Arg}^{11}$ to $\mathrm{N}$-acetyl $\beta$-endorphin(1-11) and $\beta$-endorphin(12-29). The former is further processed to $\mathrm{N}$-acetyl $\beta$-endorphin(1-10) by a carboxypeptidase $\mathrm{H}$-like enzyme. The second pathway includes cleavage of either $\mathrm{N}$-acetyl $\beta$-endorphin(1-33) or (1-29) at $\mathrm{Lys}^{21}$ to $\mathrm{N}$-acetyl $\beta$-endorphin(1-21). Processing at monobasic cleavage sites has been reported in the toad, Bufo marinus (Dores et al. 1994) and in rat prodynorphin processing (Day et al. 1998). N-acetyl $\beta$-endorphin is further truncated to $\mathrm{N}$-acetyl $\beta$-endorphin(1-15) by carboxypeptidase activity. All of the predicted $\mathrm{N}$-acetyl $\beta$-endorphin truncated forms were present in pars intermedia homogenates of the carp, except for $\mathrm{N}$-acetyl $\beta$-endorphin(1-11), (1-20), and (1-21). Therefore, we predict the conversion of the latter isoforms to be immediate and complete. In fact, it is well known that carboxypeptidases effectively cleave off C-terminal basic amino acid residues. Takahashi et al. (1984) demonstrated the presence of $\mathrm{N}$-acetyl $\beta$-endorphin(1-20) in chum salmon (Oncorhynchus keta) pituitary gland. However, the C-terminal amino acid residue in this species is Leu rather than Arg or Lys, which is less effectively removed by such enzymatic activity. The absence of carp N-acetyl $\beta$-endorphin(1-20) and (1-21) can also be explained when the full length peptide is immediately cleaved at the Leu ${ }^{19}-\mathrm{Phe}^{20}$ bond, as has been described in rats (Burbach et al. 1981).
The terminal products of the two processing routes are released by the carp pars intermedia in vitro, together with $\mathrm{N}$-acetyl $\beta$-endorphin(1-29) and/or (1-33) and trace amounts of $\mathrm{N}$-acetyl $\beta$-endorphin(1-18). In plasma, we found either $\mathrm{N}$-acetyl $\beta$-endorphin(1-15) or $\mathrm{N}$-acetyl $\beta$-endorphin(1-29)/(1-33). As the occurrence of these forms appeared to be individual-specific, we speculate that their release is under different hypothalamic control. The presence of $\mathrm{N}$-acetyl $\beta$-endorphin(1-10) and (1-18) could not be demonstrated in plasma and their concentration may be under the detection limit of the assay $(50 \mathrm{pM})$ or, alternatively, their secretion is under inhibitory hypothalamic control in vivo.

The processing pathway of $\mathrm{N}$-acetyl $\beta$-endorphin appears to be similar to the mechanism in other vertebrates, since $\mathrm{N}$-acetyl $\beta$-endorphin(1-29) (the homologue of mammalian $\mathrm{N}$-acetyl $\beta$-endorphin(1-27)), as well as $\mathrm{N}$-acetyl $\beta$-endorphin(1-18), (the homologue of $\mathrm{N}$-acetyl $\alpha$-endorphin), and $\mathrm{N}$-acetyl $\beta$-endorphin(1-19) (the homologue of $\mathrm{N}$-acetyl $\gamma$-endorphin) were found. On the other hand, we could not identify the carp homologue of $\beta$-endorphin(1-26), which may be due to the presence of $\mathrm{Gln}^{29}$ that is less susceptible to carboxypeptidase activity (Smyth et al. 1989) than is $\mathrm{His}^{27}$ in mammals. Cleavage to $\mathrm{N}$-acetyl $\beta$-endorphin(1-10) resembles processing as observed in the amphibian Xenopus laevis, where the homologue of this carp $\beta$-endorphin, $N$-acetyl $\beta$-endorphin(1-8), is the terminal product of endorphin processing (Van Strien et al. 1993). Although a minor product in the carp pituitary gland $(3 \cdot 1 \%), \mathrm{N}$-acetyl 

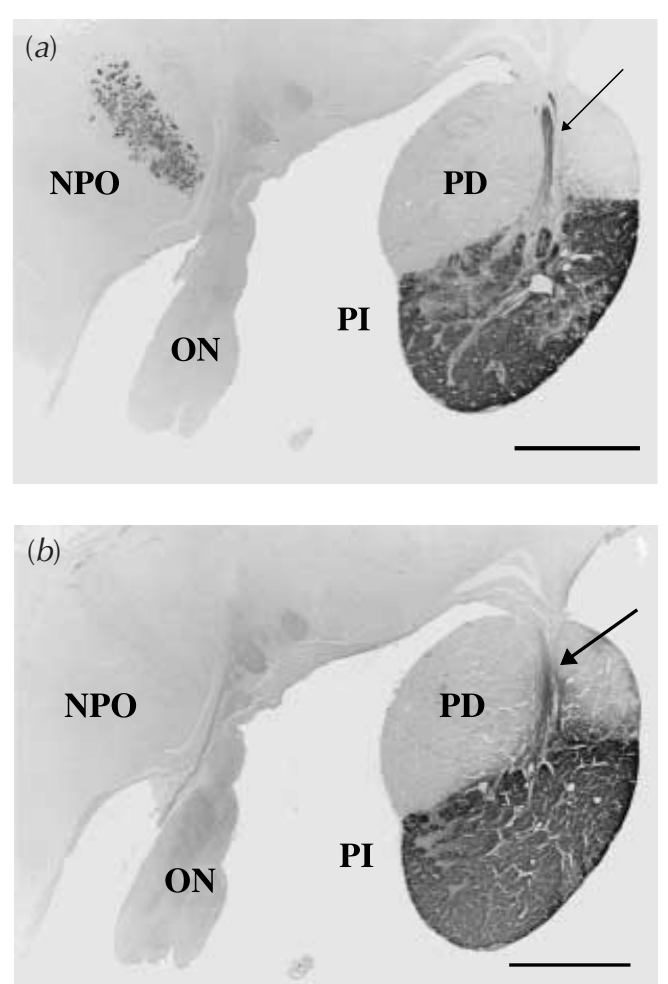

Figure 7 Sagittal section of carp brain showing the hypothalamopituitary complex. (a) $\beta$-endorphin staining is observed in the nucleus preopticus (NPO), the hypothalamo-hypophyseal tract (arrow), and in the pars intermedia (PI). The antibody recognises $\beta$-endorphin(1-29) and (1-33) as well as their acetylated counterparts. (b) The antibody against acetylated $\beta$-endorphins only stains the melanotroph cells in the $\mathrm{Pl}$, demonstrating that acetylation does not occur in the NPO and the hypothalamohypophyseal tract. The sections shown are $35 \mu \mathrm{m}$ apart, and both contain cells from the NPO as demonstrated by staining for CRF (not shown). ON, optic nerve; PD, pars distalis. Scale bar is $1 \mathrm{~mm}$.

$\beta$-endorphin(1-10) may be the most abundant $\beta$ endorphin in tilapia (Oreochromis mossambicus; Lee et al. 1999), indicating that utilisation of this pathway - which is not found in mammals - differs among fish species. Thus, in species where $\mathrm{N}$-acetyl $\beta$-endorphin is preferentially truncated to $\mathrm{N}$-acetyl $\beta$-endorphin(1-10), the $\beta$-endorphin may have a specific function not encountered in other species, or forms other than $\mathrm{N}$-acetyl $\beta$ endorphin(1-10) exert similar effects.

The reason why mammalian $\alpha$-endorphin is not further processed to $\beta$-endorphin(1-13), similar to carp $\beta$ endorphin(1-15), may relate to species-specific processing. Indeed, Takahashi et al. (1984) found no cleavage of the salmon homologue of $\mathrm{N}$-acetyl $\alpha$-endorphin. The C-terminal amino acid of $\gamma$-endorphin is Trp in all species examined, but the preceding amino acid varies. For instance, this amino acid is Leu in the carp (Arends et al. 1998), Ile in the chum salmon (Takahashi et al. 1984) and Val in humans (Takahashi et al. 1981). It appears that proteolytic activity depends not only on the nature of the C-terminal amino acid residue, but also on the neighbouring amino acids.

We were unable to identify non-acetylated $\beta$ endorphins by ESMS, although the presence of one such form was indicated by radioimmunoassay. It coeluted with synthetic carp $\beta$-endorphin(1-29) (not shown), which is likely to have the same hydrophobicity as carp $\beta$-endorphin(1-33). As measuring of these forms is possible only after chemical acetylation, it could be argued that an artefact induced by the acetylation procedure accounts for the occurrence of this immunoreactivity in the assay. However, this method has been shown to acetylate non-acetylated $\beta$-endorphins effectively (Lorenz et al. 1986, Van Strien et al. 1993). A more likely explanation is that the amount of the non-acetylated forms was too small for detection by ESMS, especially since the $\beta$-endorphins were only partially purified. In mammals, the nonacetylated $\beta$-endorphin present in the anterior pituitary corticotroph cells is the full length peptide, which is not further processed, because PC2 is hardly expressed in these cells (Benjannet et al. 1991). Using $32 \mathrm{~g}$ chum salmon pituitary glands, Takahashi et al. (1984) were able to isolate and identify full length non-acetylated $\beta$-endorphin, which must have been produced by the corticotroph cells in the pars distalis. We assume that the same applies to carp, and therefore suggest the presence of $\beta$ endorphin(1-33) in the pars distalis homogenates. The release of this peptide would be under stimulatory control of CRF, as indicated by the strong induction of its release by this neuropeptide in vitro. The trace amounts of non-acetylated $\beta$-endorphin in the pars intermedia may originate from the hypothalamic-hypophyseal tract that we showed to contain non-acetylated $\beta$-endorphin(1-33) in carp. This peptide was not released by the melanotroph cells in the pars intermedia in vitro, not even in the presence of CRF (not shown). Thus, the non-acetylated $\beta$-endorphin in plasma must originate from the pars distalis and probably represents the full length peptide.

In human plasma, the most abundant $\beta$-endorphin isoform is the opioid $\beta$-endorphin(1-31) (Silberring et al. 1998). The existence of opiate active $\beta$-endorphins in teleosts is indicated by the localisation of $\mu$-opiate receptors in the coho salmon (Oncorhynchus kisutch) brain (Ebbesson et al. 1996).

In addition to their opioid activity, $\beta$-endorphins may be involved in the stress response. We showed that CRF, which has a pivotal role in stress in all vertebrates and is a potent stimulator of ACTH and MSH secretion in fish (Van Enckevort et al. 2000), induces $\beta$-endorphin release from the pars distalis in vitro. This indicates co-release with ACTH, being a well-known corticotrophic hormone in fish (Wendelaar Bonga 1997). In contrast, CRF failed to increase the release of acetylated $\beta$-endorphins from the pituitary gland in our study, and this does not support a role for these peptides in the stress response of carp, 


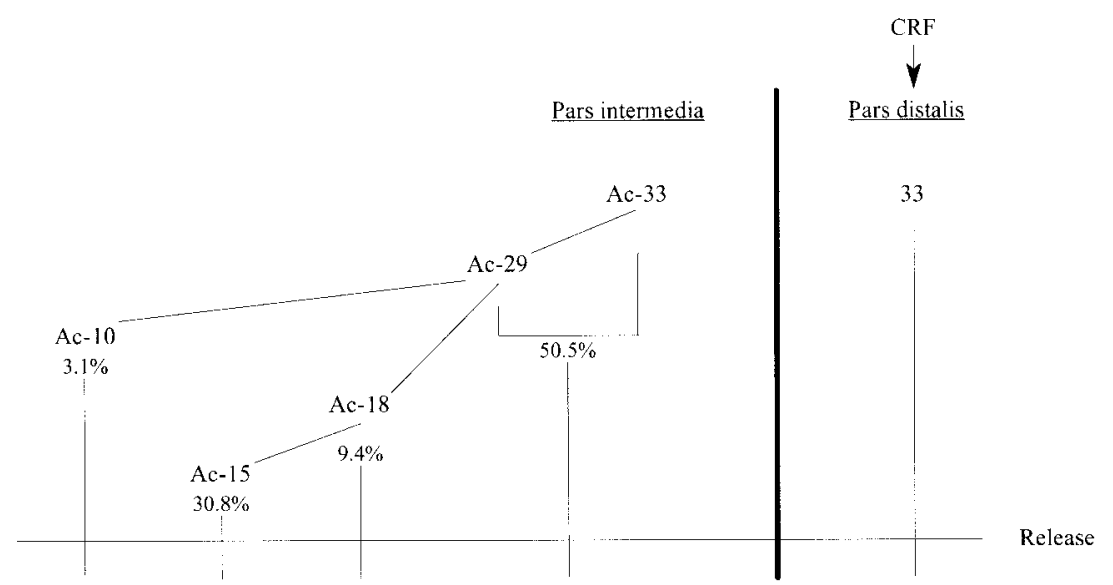

Figure 8 Summary of $\beta$-endorphin processing in the common carp. Immediately after cleavage out of POMC, $\beta$-endorphin is $\mathrm{N}$-terminally acetylated in the pars intermedia to $\mathrm{N}$-acetyl $\beta$-endorphin(1-33) (Ac-33). This peptide is further processed to $\mathrm{N}$-acetyl $\beta$-endorphin(1-29) (Ac-29), which is partially processed to $\mathrm{N}$-acetyl $\beta$-endorphin(1-10) (Ac-10) and $\mathrm{N}$-acetyl $\beta$-endorphin(1-18) (Ac-18). The bulk of the latter is cleaved to $\mathrm{N}$-acetyl $\beta$-endorphin(1-15) (Ac-15). N-acetyl $\beta$-endorphin(1-33) and/or (1-29), (1-18), $(1-15)$ and $(1-10)$ are released by the pituitary gland in vitro. In the pars distalis, $\beta$-endorphin is produced and released only when stimulated with CRF. No further processing of $\beta$-endorphin(1-33) (33) takes place. Percentages indicate the relative amount of the $\beta$-endorphins in the pars intermedia. For clarity, intermediate cleavage products are omitted from the scheme.

although increased plasma levels during stress have been reported for other fish species (Sumpter et al. 1985, Mosconi et al. 1998) as well as mammals (Akil et al. 1985). A factor other than CRF may be involved in the control of $\mathrm{N}$-acetyl $\beta$-endorphin release in carp.

In summary, $\beta$-endorphin processing in carp, of which the main steps are emphasised in Fig. 8, displays the same pattern as reported for other vertebrates. $\alpha-\mathrm{N}$-acetylation of $\beta$-endorphin(1-33) and subsequent processing to truncated forms take place only in the melanotroph cells in the pars intermedia, whereas $\beta$-endorphin(1-33) becomes detectable in the corticotroph cells of the pars distalis when stimulated with CRF. The presence of at least three $\beta$-endorphins in the circulation suggests that posttranslational modifications of $\beta$-endorphin expand the possibilities for multiple physiological effects. These findings warrant the search for regulatory mechanisms in the release of the different $\beta$-endorphins.

\section{Acknowledgements}

This work was partially supported by SLW 805-33101-P. The authors gratefully acknowledge $\mathrm{Mr} \mathrm{T}$ Spanings for animal care. BD is a postdoctoral fellow of the Funds for Scientific Research - Flanders. J V B is indebted to the same institute for research grant G.0422.98.

\section{References}

Akil H, Young E, Watson SJ \& Coy DH 1981 Opiate binding properties of naturally occurring $\mathrm{N}$ - and C-terminal modified $\beta$-endorphins. Peptides 2 289-292.

Akil H, Shiomi H \& Matthews J 1985 Induction of the intermediate pituitary by stress: synthesis and release of a nonopioid form of $\beta$-endorphin. Science 227 424-426.

Arends RJ, Vermeer H, Martens GJM, Leunissen JAM, Wendelaar Bonga SE \& Flik G 1998 Cloning and expression of two proopiomelanocortin mRNAs in the common carp (Cyprinus carpio L.). Molecular and Cellular Endocrinology 143 23-31.

Balm PHM, Hovens MLM \& Wendelaar Bonga SE 1995 Endorphin and MSH in concert form the corticotropic principle released by tilapia (Oreochromis mossambicus; Teleostei) melanotropes. Peptides 16 463-469.

Benjannet S, Rondeau N, Day R, Chrétien M \& Seidah NG 1991 PC1 and PC2 are proprotein convertases capable of cleaving pro-opiomelanocortin at distinct pairs of basic residues. PNAS $\mathbf{8 8}$ 3564-3568.

Burbach JPH, De Kloet ER, Schotman P \& De Wied D 1981 Proteolytic conversion of $\beta$-endorphin by brain synaptic membranes. Characterization of generated $\beta$-endorphin fragments and proposed metabolic pathway. Journal of Biological Chemistry 256 12463-12469.

Dalayeun JF, Norès JM \& Bergal S 1993 Physiology of $\beta$-endorphins. A close-up view and a review of the literature. Biomedicine and Pharmacotherapy 47 311-320.

Day R, Lazure C, Basak A, Boudreault A, Limperis P, Dong W \& Lindberg I 1998 Prodynorphin processing by proprotein convertase 2. Cleavage at single basic residues and enhanced processing in the presence of carboxypeptidase activity. Journal of Biological Chemistry 273 829-836. 
Dores RM, Steveson TC \& Lopez K 1991 Differential mechanisms for the $\mathrm{N}$-acetylation of $\alpha$-melanocyte-stimulating hormone and $\beta$-endorphin in the intermediate pituitary of the frog, Xenopus laevis. Neuroendocrinology 53 54-62.

Dores RM, Gieseker K \& Steveson TC 1994 The posttranslational modification of $\beta$-endorphin in the intermediate pituitary of the toad, Bufo marinus, includes processing at a monobasic cleavage site. Peptides 15 1497-1504.

Ebbesson LOE, Diviche P \& Ebbesson SOE 1996 Distribution and changes in $\mu$ - and $\kappa$-opiate receptors during the midlife neurodevelopmental period of coho salmon, Oncorhynchus kisutch. Journal of Comparative Neurology 364 448-464.

Faletti AG, Mastronardi CA, Lomniczi A, Seilicovich A, Gimeno M, McCann SM \& Rettori V 1999 -endorphin blocks luteinizing hormone-releasing hormone release by inhibiting the nitricoxidergic pathway controlling its release. PNAS 96 1722-1726.

Heijnen CJ, Croiset G, Zijlstra J \& Ballieux RE 1987 Modulation of lymphocyte function by endorphins. Annals of the New York Academy of Sciences 496 161-165.

Kjær A, Knigge U, Bach FW \& Warberg J 1995 Stress-induced secretion of pro-opiomelanocortin-derived peptides in rats: relative importance of the anterior and intermediate pituitary lobes. Neuroendocrinology 61 167-172.

Lee J, Danielson P, Sollars C, Alrubaian J, Balm P \& Dores RM 1999 Cloning of a neoteleost (Oreochromis mossambicus) POMC cDNA reveals a deletion of the $\gamma$-MSH region and most of the joining peptide region: implications for POMC processing. Peptides $\mathbf{2 0}$ 1391-1399.

Lorenz RG, Tyler AN, Faull KF, Makk G, Barchas JD \& Evans CJ 1986 Characterization of endorphins from the pituitary of the spiny dogfish, Squalus acanthias. Peptides 7 119-126.

Millington WR, Dybdal NO, Mueller GP \& Chronwall BM 1992 $\mathrm{N}$-acetylation and C-terminal proteolysis of $\beta$-endorphin in the anterior lobe of the horse pituitary. General and Comparative Endocrinology 85 297-307.

Mosconi G, Gallinelli A, Polzonetti-Magni AM \& Facchinetti F 1998 Acetyl salmon endorphin-like and interrenal stress response in male gilthead sea bream, Sparus aurata. Neuroendocrinology 68 129-134.

Nicolas P \& Li CH $1985 \beta$-endorphin(1-27) is a naturally occurring antagonist to etorphine-induced analgesia. PNAS 82 3178-3181.

Rodrigues KT \& Sumpter JP 1984 The radioimmunoassay of $\alpha$-melanocyte-stimulating hormone and endorphin in trout (Salmo gairdneri) and the effect of blinding on the plasma levels of these peptides. General and Comparative Endocrinology 54 69-75.

Sælsen L, Andersen HB, Bratholm P \& Christensen NJ 1994 Radioimmunoassay of plasma neuropeptide Y using HPLC for separation of related peptides and fragments. Scandinavian Journal of Clinical and Laboratory Investigation 54 207-214.

Salacinsky PRP, McLean C, Sykes JEC, Clement-Jones VV \& Lowry P 1981 Iodination of proteins, glycoproteins, and peptides using a solid-phase oxidizing agent 1,3,4,6,-tetrachloro-3 $\alpha, 6 \alpha$-diphenyl glycoluril (Iodogen). Analytical Biochemistry 117 136-146.
Shahabi NA, Burtness MZ \& Sharp BM 1991 N-acetyl- $\beta$ endorphin $_{1-31}$ antagonizes the suppressive effect of $\beta$-endorphin131 on murine splenocyte proliferation via a naloxone-resistant receptor. Biochemical and Biophysical Research Communications $\mathbf{1 7 5}$ 936-942.

Shahabi NA, Heagy W \& Sharp BM 1996 -endorphin enhances concanavalin-A-stimulated calcium mobilization by murine splenic T cells. Endocrinology 137 3386-3393.

Silberring J, Li YM, Terenius L \& Nylander I 1998 Characterization of immunoreactive dynorphin B and $\beta$-endorphin in human plasma. Peptides 19 1329-1337.

Smyth DG 1984 Chromatography of peptides related to $\beta$-endorphin. Analytical Biochemistry 136 127-135.

Smyth DG, Maruthainar K, Darby NJ \& Fricker LD 1989 Catalysis of slow C-terminal processing reactions by carboxypeptidase H. Journal of Neurochemistry 53 489-493.

Sumpter JP, Pickering AD \& Pottinger TG 1985 Stress-induced elevation of plasma $\alpha-\mathrm{MSH}$ and endorphin in brown trout, Salmo trutta L. General and Comparative Endocrinology 59 257-265.

Takahashi H, Teranishi Y, Nakanishi S \& Numa S 1981 Isolation and structural organization of the human corticotropin-beta-lipotropin precursor gene. FEBS Letters 135 97-102.

Takahashi A, Kawauchi H, Mouri T \& Sakai A 1984 Chemical and immunological characterization of salmon endorphins. General and Comparative Endocrinology 53 381-388.

Van der Heijden AJH, Van der Meij JCA, Flik G \& Wendelaar Bonga SE 1999 Ultrastructure and distribution dynamics of chloride cells in tilapia larvae in fresh water and sea water. Cell and Tissue Research 297 119-130.

Van Enckevort FHJ, Pepels PPLM, Leunissen JAM, Martens GJM, Wendelaar Bonga SE \& Balm PHM 2000 Oreochromis mossambicus (tilapia) corticotropin-releasing hormone: cDNA sequence and bioactivity. Journal of Neuroendocrinology 12 177-186.

Van Strien FJC, Jenks BG, Heerma W, Versluis C, Kawauchi H \& Roubos EW $1993 \alpha, N$-acetyl- $\beta$-endorphin is the terminal product of processing of endorphins in the melanotrope cells of Xenopus laevis, as is demonstrated by FAB tandem mass spectrometry. Biochemical and Biophysical Research Communications 191 262-268.

Weber E, Evans CJ \& Barchas JD 1981 Acetylated and non-acetylated forms of $\beta$-endorphin in rat brain and pituitary. Biochemical and Biophysical Research Communications 103 982-989.

Wendelaar Bonga SE 1997 The stress response in fish. Physiological Reviews 77 591-625.

Zhou A, Bloomquist BT \& Mains RE 1993 The prohormone convertases PC1 and PC2 mediate distinct endoproteolytic cleavages in a strict temporal order during pro-opiomelanocortin biosynthetic processing. Journal of Biological Chemistry 268 1763-1769.

Received 12 October 2000

Accepted 31 January 2001 